\title{
Pelembagaan Program Kampung Keluarga Berencana di Kelurahan Karangpucung Kecamatan Purwokerto Selatan Kabupaten Banyumas
}

\author{
Andi Antono', Ngalimun², Sri Weningsih ${ }^{3}$, Darmanto Sahat Satyawan ${ }^{4}$ \\ 1,2,4 Fakultas Ilmu Sosial dan Ilmu Politik Universitas Soedirman, Purwekerto, Indonesia \\ ${ }^{3}$ UPBJJ-Universitas Terbuka, Purwokerto, Indonesia
}

\begin{abstract}
The Kampung KB Program is a development program that aims to improve the quality of the population in Indonesia. An important aspect in this program is community empowerment. Development with an empowerment dimension is a development activity that occurs in society which is triggered by the desire to advance and allow economic growth and social cohesiveness. This program is a button up, where the government acts as a facilitator and the community innovates according to the issues and needs that develop in the local community.

In Banyumas Regency, the program received serious attention from stakeholders so that this stretch was evident in the slogans of the KB village that are often found in almost every sub-district and village / kelurahan. This research was conducted in Karangpucung Village, South Purwokerto District, by observing community activities related to the Kampung KB Program in conducting program socialization and collaboration with other parties, such as sub-district and district governments, community leaders, and experts in the population sector. .

The results of the research, which was conducted in a descriptive qualitative manner, showed that for enabling links, the PKK officials were assisted by the head of the RT / $R W$ aggressively and voluntarily to socialize by going from house to house to raise awareness of the residents. The material is not only about family planning but also about local productive businesses and entertainment. For functional relations, this program involves the Puskesmas, family planning officers, midwives and also Babinsa who take an active role. The normative link is that the program is run through the main tasks and functions outlined by the BKKN, instructions and guidance from policy makers such as the sub-district head, village head and the head of district PKK supervisors. Meanwhile, related to the dissemination of the $K B$ village program, it uses events that are widely liked by the community such as grand recitation, art competitions (kentongan), socialization of the risks of early marriage for youth groups, and the provision of supporting facilities, namely props for counseling, as well as the availability of libraries in KB villages.
\end{abstract}

Keywords: KB Village, Institutionalization and Empowerment. 


\section{Pendahuluan}

Problem fertilitas di Indonesia hingga hari ini masih fokus utama dalam upaya membangun manusia seutuhnya. Jika pertumbuhan penduduk terus meningkat tanpa terkendali maka upaya mensejahterakan rakyat dan bahkan membangun kualitas manusia Indonesia sulit akan tercapai. Berbagai program kependudukan telah dilakukan dan usaha ini harus terus menerus didorong supaya tidak mengalami stagnasi, karena kegagalan program kependudukan akan berdampak pada problem lainnya yaitu problem produktivitas ekonomi dan sosial. Salah satu program kependudukan yang sekarang dikembangkan oleh pemerintah adalah Program Kampung Keluarga Berencana (KB). Program Kampung KB diinisiasi oleh pemerintah tetapi dalam pelaksanaannya masyarakat diberi kepercayaan untuk berinovasi secara mandiri termasuk dalam pengelolaan dana. Masyarakat diberi stimulan dana dan panduan yang harus dilakukan dan pada saat yang sama masyarakat diharapkan berkolaborasi dengan berbagai pihak untuk menggerakkan masyarakat agar masyarakat sadar akan pentingnya program tersebut.

Di Kabupaten Banyumas program tersebut telah mendapat perhatian yang serius dari para stakeholder sehingga geliat ini nampak pada slogan-slogan kampung KB yang sering ditemui hampi disetiap kecamatan, kelurahan maupun di desa-desa. Salah satu kelurahan yang sangat aktif dalam pelaksanaan Program Kampung KB adalah di Kelurahan Karangpucung Kecamatan Purwokerto Selatan, yang

selanjutnya akan menjadi lokus dalam penelitian ini. Melalui program kampung KB, apakah masyarakat menyadari akan pentingnya manfaat program? Karena itu usaha terus menerus yang dilakukan oleh para pegiat program diharapkan masyarakat dapat menjadikan program Kampung KB sebagai norma baru yang diakui dan ditaati. Sebagai ilustrasi, keluarga yang memiliki jumlah anak yang sedikit (satu atau dua anak) akan lebih mudah menata masa depan anak-anak dibanding keluarga yang memiliki jumlah anak yang banyak. Pemberdayaan tentunya yang menjadi inti dari pembangunan baik di desa maupun di kota dan program Kampung KB merupakan pendulum bagi programprogram pembangunan lainnya.

Pembangunan

yang

berdimensi pemberdayaan merupakan kegiatan pembangunan yang terjadi pada masyarakat desa yang dipicu oleh keinginan untuk maju dan memungkinkan terjadinya pertumbuhan ekonomi yang terus menerus disertai dengan pemerataan sehingga dalam jangka panjang akan terjadi efek simultan antara petumbuhan ekonomi, peningkatan konsumsi masyarakatdan tabungan masyarakat desa setempat. Kegiatan pembangunan seperti itu jika ditelurusi mengandung unsur pemberdayaan karena selain meningkatkan pertumbuhan ekonomi juga ada transformasi sosial dan politik masyarakat, yaitu yang menghasilkan menikmati dan sebaliknya yang menikmati haruslah menghasilkan. Model pembangunan seperti ini sangat tepat untuk kondisi yang telah membiasakan diri pada kemandirian dan otonomi warganya, 
sebagaimana dituangkannya undangundang desa.

Menurut Soleh (2014), terdapat 4 prinsip yang harus dijadikan pegangan dalam pembangunan yg berdimensi pemberdayaan yaitu:

Pertama, Pembangunan harus terarah dan ditujukan secara langsung kepada yang memerlukan; Kedua, Program sengaja dirancang untuk memecahkan masalah, sesuai dengan kebutuhannya; Ketiga, Aktor utama penyusunan dan pelaksanaan program/proyek adalah masyarakat sendiri; dan Keempat, Penggunaan pendekatan kelompok, karena secara individual, masyarakat miskin sulit memecahkan masalah-masalah yang dihadapinya.

$$
\text { Untuk melaksanakan }
$$

pembangunan desa yang memberdayakan tersebut diperlukan kerjasama antar elit untuk berkolaborasi dalam menentukan prioritas pembangunan ataupun pembangunan yang dapat memenuhi kebutuhan masyarakatnya, kerjasama antar elit tersebut orang menyebutnya sebagai model kolaboratif yang terjadi pada struktur pemerintahan baik di tingkat desa ataupun tingkat yang paling tinggi yaitu pemerintah. Pemerintahan yang kolaboratif adalah serangkaian pengaturan dimana satu atau lebih lembaga politik yang melibatkan secara langsung stakeholder non state di dalam proses pembuatan kebijakan yang bersifat formal, berorientasi konsesi dan deleberatif yang bertujuan untuk membuat atau mengimplentasikan kebijakan publik atau mengatur program publik.

Paradigma pemberdayaan atau empowerment pada dasarnya menawarkan alternative pengentasan kemiskinan dan keterbelakangan dengan member kesempatan/kepercayaan kepada kelompok masyarakat miskin (tuna daya) untuk merencanakan dan kemudian melaksanakan program pembangunan yang mereka pilih dan putuskan atau yang dikenal dengan model pemberdayaan masyarakat. Berbeda dengan model pembangunan partisipatif yang menitikberatkan masyarakat pada kesempatan masyarakat untuk merencanakan dan melaksananakan, sedangkan model pembangunan pemberdayaan selain masyarakat terlibat aktif dalam proses perencanaan dan pelaksanaan, mereka juga diberikan kewenangan untuk mengelola sejumlah dana untuk melaksanakan program tersebut.

2009, ada dua versi model pemberdayaan masyarakat, yaitu (1) model pemberdayaan versi Paul Freire yang menekankan pemberdayaan dengan pendekatan politik dan (2) model pemberdayaan versi Schemaker yang menekankan pemberdayaan denganpendekatan ekonomi. Sementara itu kesamaan dari kedua versi tersebut adalah sama-sama menekankan akan adanya agen pembangunan yang mau bekerjasama dengan kelompok penduduk setempat untuk membangun kemandirian. Kedua versi model pemberdayaan dengan pendekatan yang berbeda tersebut dalam prakteknya akan sulit dilaksanakan. Pemberdayaan masyarakat versi Paulo Freire akan dihadapkan pada kepentingan yang lebih kuat dan dominan dalam masyarakat, sementara model pemberdayaan versi schumaker yang 
menekankan pada pentingnya pembentukan kelompok mandiri juga tidak akan banyak mempunyai arti tanpa adanya dukungan politik. Dengan demikian pada dasarnya kedua versi model tersebut diperlukan secara secara bersamasama, saling melengkapi untuk memecahkan masalah kemiskinan dan keterbelakangan.

Lebih lanjut berkenaan dengan upaya pencapaian tujuan umum perberdayaam tersebut Bank Dunia (2002) mensyaratkan adanya perbaikan: (a) Modal financial yang berupa perencanaan ekonomi makro dan dan pengelolaan fiscal; (b) Perbaikan modal fisik, berupa prasarana bangunan, mesin pelabuhan; (c) Perbaikan modal SDM berupa perbaikan kesehatan dan pendidikan yang relevan dengan pasar kerja; (d) Pengembangan modal sosial yang menyangkut keterampilan, pengetahuan, kelembagaan, kemitraan dan norma hubungan social; (e) Pengelolaan sumberdaya alam baik yang bersifat komersial dan non komersial seperti ketersediaan air bersih, energi, pengelolaan limbah dan beragam.

Adapun mekanisme kegiatan pemberdayaan masyarakat adalah sebagai berikut: (a) Penumbuhan hasrat atau keinginan untuk mau berubah; (b) Menumbuhkan kemauan dan keberanian; (c) Mengembangkan kemauan dan ambil bagian (berpartisipasi); (d) Peningkatan peran dalam kegiatan; (e) Peningkatan efesiensi dan efektifitas; dan (f) Peningkatan kompetensi diri secara otomatis

Selanjutnya setiap wilayah dalam suatu negara seperti negara Indonesia, berjuang untuk mencapai tujuan pembangunan. pembangunan dalam menciptakan kesejahteraan, keadilan sosial, mencerdaskan bangsa dan penegakan hukum dll. pembangunan yang mencakup seluruh komponen tersebut merupan tugas yang sangat berta jika di bebankan kepada suatu pihak individu. Oleh karena itu, merupakan kewajiban dari seluruh komponen yang ada dalam suatu bangsa untuk bahu-membahu, berjuang dalam pencapaian tujuan besar tersebut. Seluruh komponen yang ada dalam suatu bangsa akan dapat bekerja dalam pencapaian tujuan dengan efektif, jika tertuang dalam kelembagaan yang kuat.

Menurut Hanafie (2010), bahwa lembaga adalah badan, organisasi, kaidah, dan norma-norma baik formal maupun informal sebagai pedoman untuk mengatur perilaku segenap anggota masyarakat baik dalam kegiatan sehari-sehari maupun dalam usahanya mencapai suatu tujuan tertentu. Lembaga-lembaga bentukan pemerintah lebih sering disempurnakan agar mampu berfungsi sebagai tumpuan untuk menunjang terciptanya pembangunan yang mantap serta sesuai dengan iklim pembangunan pertanian dan pedesaan. Bentuk kelembagaan dapat dikelompokkan menjadi 2 yaitu kelembagaan primer dan kelembagaan sekunder. Unsurunsur kelembagaan primer mencakup pemerintah, kekayaan, industri, pendidikan, agama dan keluarga.

Menurut Anantanyu (tahun
2011) kelembagaan
keseluruhan pola-pola ideal,
organisasi, dan aktivitas yang
berpusat di sekeliling kebutuhan
dasar seperti kehidupan keluarga,
negara, agama dan mendpatkan


makanan, pakaian, dan kenikmatan serta tempat perlindungan. Suatu lembaga dibentuk selalu bertujuan untuk memenuhi berbagai kebutuhan manusia sehingga lembaga mempunyai fungsi. Lembaga juga merupakan konsep yang berpadu dengan struktur, artinya tidak saja melibatkan pola aktivitas yang lahir dari segi sosial untuk memenuhi kebutuhan manusia, tetapi juga pola organisasi untuk melaksanakannya. Sedangkan menurut Nugroho, Tahun 2010 kelembagaan diartikan sebagai aturan main, norma-norma, laranganlarangan, kontrak, kebijakan dan peraturan atau perundangan yang mengatur dan mengendalikan perilaku individu dalam masyarakat atau organisasi untuk mengurangi ketidakpastian dalam mengontrol lingkungannya serta menghambat munculnya perilaku oportunis dan saling merugikan sehingga perilaku manusia dalam memaksimumkan kesejahteraan individualnya lebih dapat diprediksi. Definisi tersebut mengimplikasikan 2 komponen penting dalam kelembagaan, yaitu aturan main (rules of the game) dan organisasi (players of the game). Keduanya sulit dipisahkan karena organisasi dapat berjalan apabila aturan main mengizinkan atau memungkinkan, sebaliknya aturan main disusun, dijalankan, dan ditegakkan oleh organisasi.

$$
\text { Tujuan akhir dari }
$$

pelembagaan adalah masyarakat secara sadar mengikuti aturan main, mematuhi norma-norma secara baik dalam rangka mewujudkan kesejahteraan bersama, hal ini sejalan dengan tujuan pemberdayaan, yaitu untuk meningkatkan harkat martabat hidup manusia, dengan kata lain secara sederhana untuk meningkatkan kualitas hidup. Perbaikan kualitas hidup bukan semata-mata menyangkut aspek ekonomi, tetapi juga fisik, mental, politik, keamanan dan social budaya.

Dalam pembangunan lembaga sejumlah variabel akan bertautan dengan kaitan-kaitan yang bekerja membentuk kekuatan lembaga. Variabel-variabel lembaga, pada dasarnya menyangkut organisasi itu sendiri yang bersifat lingkungan internal yang harus berhubungan dengan lingkungan eksternal yang berupa kaitan-kaitan. Variabel tersebut yaitu: variabel kepemimpinan, variabel doktrin, variabel program dan variabel sumberdaya.

Variabel yang paling penting adalah kepemimpinan. Bimbingan memerlukan kepemimpinan, dan hal ini khususnya berlaku dimana persoalannya, bukanlah untuk mempertahankan status quo. Suatu organisasi tanpa kepemimpinan mungkin akan menjadi tak terkendali dan terkecuali bila kepemimpinan adalah komponen secara teknis dan secara politis. Gaya-gaya kepemimpinan alternatif mungkin akan secara berarti mempengaruhi bekerjanya suatu organisasi baru yang telah disusun kembali yang telah mengikatnya dirinya ke inovasi. Variabel doktrin adalah variabel lembaga yang paling sulit dipahami. Ia adalah pengungakapan dari apa yang diwakili oleh organisasi tersebut, apa yang diharapkannya untuk dicapai dan gaya-gaya tindakan yang akan digunakannya sebagai motivasi orang untuk bertindak. Doktrin bukanlah suatu konsep tunggal tetapi lebih banyak merupakan sekelompoktema yang diproyeksi oleh kepemimpinan ke 
audience intern dan eksternny. Dengan demikian maka doktrin memberikan motivasi kepada pegawai. Jadi perluasan, pengungkapan, dan manipulasi dari doktrin adalah tanggung jawab yang penting dari mereka yang membina kegiatan-kegiatan PL. Hal ini adalah suatu tahap dari manejemen kelembagaan dimana waktu, pemikiran dan usaha harus ditanam namun sering diabaikan. Program organisasi adalah seperangkat kegiatan-kegiatan yang dijalankannya, penerjemahan doktrin ke dalam tindakan dengan melalui program-program tindakannya maka inovasi-inovasi teknologi dan social yang diwakili lembaga akan diubah menjadi produk-produk atau jasajasa spesifik.

Variabel Program. Programprogram tindakan cenderung dirumuskan sebagai tanggapan terhadap mandat-mandat legal, kesempatan-kesempatan atau prioritas-prioritas yang dipegang oleh kepemimpinan. Biasanya prioritas tersebut membantu inovasiinovasi dengan mana kepemimpinan telah mengikat dirinya. Tetapi program-program tidak dirumuskan dalam kekosongan karena harus dirancang dan dikelola sedemikian rupa sehingga akan membangun dukungan bagi organisasi tersebut di antara calon "masyarakat" dan meminimalkan oposisi. Organisasi telah menyiapkan program-program yang bersedia diterima oleh caloncalon masyraraktnya dengan membangun suatu "program mix". Karena pembuatan program khususnya bagi suatu organisasi yang inovatif adalah suatu proses yang dinamis; ia tidak dapat ditetapkan sekali saja dan untuk selama- lamanya. Pengembangan program harus konsisten dengan sumbersumberdaya yang tersedia bagi organisasi tersebut pada tiap saat atau ia tidak akan mampu menyediakan jasa-jasa. Besarnya dan mutu dari sumber-sumberdaya yang tersedia bagi kepemimpinan adalah determinan-determinan yang penting dari efektifnya suatu organisasi. Program-program hendaknya menghasilkan manfaat dan kepuasaan bagi perorangan dan kelompok-kelompok dalam masyarakat yang mempertahankan dan menaikkan pencapaian yang terus menerus oleh organisasi ke sumber-sumberdaya.

Variabel sumberdaya tidaklah lamban sifatnya. Mereka harus dikembangkan, digabung dan disebarkan sebelum dapat menghasilkan keluaran-keluaran yang berguna. Sumberdaya yang paling penting dalam organisasi adalah stafnya. Pengembangan staf adalah fungsi yang terus-menerus dari para pembangun lembaga dengan ketrampilan,pengetahuan, komitmen-komitmen yang deprogram bagi hasil kerja yang efektif yang diperlukan oleh suatu organisasi yang inovatif jarang tersedia dalam pasar tenaga kerja. Jadi kepemimpinan harus menanam tenaga dalam menetapkan suatu sistem informasi dan mempertahankan Dana bukan satusatunya sumber daya yang diperlukan organisasi, namun dana sangat diperlukan untuk membiayai segala fasilitas dan semua aktivitas yang sedang berlaku. Tiap organisasi (termasuk organisasi yang sedang menjadi lembaga) harus mencapai kompetensi teknis dan kepaduan yang efektif diantara semua 
komponennya. Kebutuhan untuk menjamin keterpaduan tersebut dimasukkan dalam suatu kelompokkelompok variable-variable yang disebut struktur intern. sumbersumberdaya informasinya pada suatu efisiensi yang tinggi. Tiap organisasi berinteraksi dengan organisasi lainnya. Dari berinteraksi tadi, organisasi yang inovatif mempersoalkan dirinya untuk selalu memperoleh dukungan dan mengatasi perlawanan. Jaringan hubungan-hubungan interorganisatoris ini dinyatakan sebagai kaitan-kaitan.

Dalam proses pelembagaan menurut Milton, J. Esman organisasi inovatif akan berusaha memperoleh dukungan dan mengatasi perlawanan, dan untuk menghasilkan perubahanperubahan organisasi akan mengadakan interaksi dan membangun jaringan Jaringan hubungan-hubungan inter organisatoris ini dinyatakan sebagai kaitan-kaitan. Untuk menyederhanakan konsep ini jenis kaitan lembaga yaitu:

Kaitan yang memungkinkan (enabling) menyediakan wewenang untuk bekerja dan mencapai sumberdaya yang esensial. Kaitan yang memungkinan ini juga dapat digunakan untuk melindungi organisasi tersebut terhadap serangan dan untuk menjamin tercapainya sumber-sumberdaya selama masa kritis sementara ia membangun kemampuankemampuannya, tetapi bulum cukup kuat untuk menghadapi lingkungan eksternalnya atas dasar keinginan sendiri.
Kaitan-kaitan fungsional menyediakan masukan-masukan yang diperlukan ke dalam organisasi dan mengambil keluarankeluarannya. Sebagai tambahan pada hubungan komplementer, kategori kaitan-kaitan ini mencakup lembaga yang adalah juga pesaing-pesaing yang nyata dan potensial. Kaitan fungsional ini umpamanya hubungan antara lembaga perencana meminta informasi (luaran) untuk mengalokasikan dana.Suatu badan penyuluhan pertanian akan mempunyai kaitan-kaitan dengan badan riset yang menyediakan baginya masukan-masukan dan dengan organisasi-otganisasi pertanian yang mengambil keluarannya..

Kaitan-kaitan normatif adalah hubungan-hubungan dengan organisasi-organisasi lainnya yang membagi suatu kepentingan yang tumpang-tindih dalam tujuan-tujuan atau metode-metode dari lembaga yang baru. Mereka ini dapat menguatkan atau bermusuhan. Jadi lembaga keluarga berencana mungkin mempunyai kaitan normatif dengan suatu kelompok agama yang dapat bersifat mendukung atau bermusuhan. Sedangkan kaitankaitan yang tersebar adalah hubungan-hubungan dengan orangorang dan kelompok-kelompok yang tidak terkumpul dalam organisasiorganisasi atau kolektivitas formal tetapi mampu mempengaruhi kedudukan dari organisasi-organisasi inovatif dalam lingkungannya.

Untuk lebih jelasnya proses pelembagaan tersbut dapat digambarkan sebagai berikut: 
Gambar 1

Mekanisme Pemangunan Lembaga

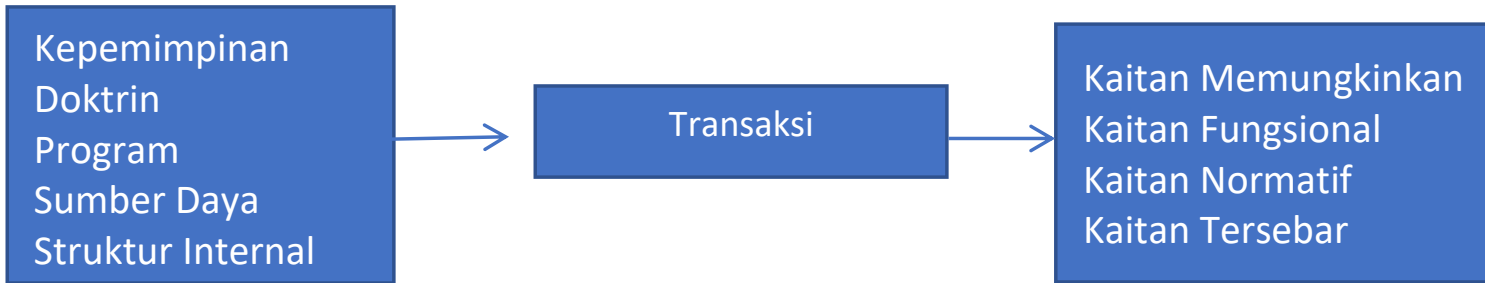

\section{Metode Penelitian}

Lokasi penelitian: Penelitian ini berlokasi di Desa Karangnanas Kecamatan Sokaraja Kabupaten Banyumas. Sasaran Penelitian: Sasaran penelitian ini adalah perangkat desa dan pemangku kepentingan, dan tokoh masyarakat di Kelurahan Karangpucung

Sampling Penelitian: Teknik pengambilan informan dilakukan secara snowball sampling dengan tetap menjaga independensi dalam mengutarakan pendapat. Teknik Pengambilan Data Metode pengumpulan data dengan wawancara mendalam, pengamatan dan analisis dokumen.

Teknik Analisis Data: Analisis data dilakukan secara interaktif, mulai dari pengumpulan data, kondensasi data, penampilan data, dan penarikan kesimpulan penelitian (Miles dan Huberman, 2012) dan dikombinasikan dengan penampilan data deskriptif.

\section{Hasil dan Pembahasan Kaitan Memungkinkan}

Suatu organisasi tanpa kepemimpinan mungkin akan menjadi tidak terkendali dan terkecuali bila kepemimpinan adalah kompeten secara teknis dan politis baik dalam kewajiban intern maupun ekstern dan telah mengiatkan dirinya ke inovasi, mungkin usaha tersebut dalam bahaya walaupun sebenarnya kesempatan-kesempatan yang ada menguntungkan baginya (Esman, 1971). Dalam hal ini ide mengenai program kampung KB memang berasal dari pemerintah, karenanya semua daerah, desa atau kampung mendapatkan akses yang sama untuk melaksanakan program tersebut. Di Kelurahan Karangpucung merupakan salah satu kelurahan yang mampu menjalankan program tersebut dengan baik. Kepemimpinan di tingkat kelurahan merespon program tersebut dengan segala kemampuan dan sumberdaya yang dimiliki.

Di awal program semua komponen stakeholder menyamakan ide dan presepsi untuk membangun doktrin tentang kampung KB. Doktrin merupakan variabel yang memerlukan ketajaman dalam menjelaskan dan gaya tindakan yang mudah dipahami oleh masyarakat. Pengungkapan doktrin dilakukan secara berulang-ulang, konsisten dan meyakinkan untuk mengembangkan konsensus pada tujuan-tujuan bersama. Agar lebih detail doktrin dijabarkan dalam bentuk program sampingan seperti sistem arisan yang dikemas dengan kegiatan yang inovatif dalam rangka mendukung program utama.

Pengerahan sumber daya berupa dana dan peralatan sudah pasti menjadi instrumen utama dalam memulai program. 
Sumberdaya dalam bentuk materi ( dana dan fasilitas) sangat diperlukan oleh operasional organisasi, termasuk sumbangan sukarela atau mungkin bantuan luar negeri. Di sini kepemimpinan formal dan lokal bekerja untuk memenuhi harapanharapan dan melayani permintaan yang menjamin aliran dana dan fasilitas yang dapat diandalkan. Salah satu pengujian penting tentang keberhasilan bantuan teknis dan kedalaman dari pembangunan lembaga adalah kemampuan organisasi yang inovatif untuk menarik dan meneruskan pengerahan dana-dana dari sumber nasional bila bantuan teknis ditarik kembali. Struktur interen dikembangkan melalui pendekatan informal dan atas dasar kebutuhan program yang direncanakan. Urusan jumlah personil tidak menjadi pertimbangan utama karena fokus utamanya dasar kesediaan dan partisipasi yang luas.

\section{Kaitan Fungsional}

Dalam kaitannya dengan kaitan fungsional disyaratkan agar kepemimpinan hendaknya mengenali batasan-batasan organisasi dan lingkungan. Kepribadian kepemimpinan yang dominan terhadap inovasi sangat diperlukan, dan inovasi dapat dibangun melalui transformasi informasi dari internal organisasi ke eksternal organisasi atau sebaliknya. Kepemimpinan garda terdepan yaitu para relawan program berusaha mendekati tokohtokoh masyarakat secara informal, termasuk para pemimpin agama. Dalam banyak kasus nilai-nilai yang agama seringkali bertentangan dengan nilai sekularisme. Slogan "dua anak cukup" merupakan bahasa yang menjadi doktrin bagi program KB yang kemudian bertentangan dengan nilai agama karena banyaknya jumlah anak menjadi urusan individu dengan Tuhan Yang Maha Kuasa. Harmonisasi hubungan antar elit di tingkat kelurahan maupun hubungannya dengan pemimpin formal menjadi bagian penting dalam memulai program. Sekalipun awalnya sulit namun para relawan program mampu membangun hubungan yang saling mengerti dengan tokoh-tokoh agama.

Doktrin bukanlah konsep tunggal tetapi suatu konsep lebih banyak ditujukan pada sekelompok tema yang diproyeksi oleh kepemimpinan ke audience intern dan ekstern untuk memperoleh dan mempertahankan dukungan organisasi tersebut dan maksudmaksudnya (Esman). Dalam doktrin ada suatu tingkat fleksibilitas, bagi bagian masyarakat yang berbeda maka tema-tema dapat diberikan tekanan yang berbeda dan mereka dapat dimodifikasi pada saat dimana organisasi tersebut menghadapi persoalan-persoalan baru dan belajar dari pengalaman.

Berkaitan dengan doktrin adalah program. Program-program tindakan cenderung dirumuskan sebagai tanggapan terhadap mandatmandat legal, tuntutan-tuntutan lingkungan, kesempatan-kesempatan atau prioritas-prioritas yang dipegang oleh pimpinan. Biasanya prioritas-prioritas tersebut membantu inovasi-inovasi yang dicanangkan oleh pemimpin lembaga. Program harus dirancang sedemikian rupa untuk meraih dukungan dan mengurangi perlawanan.

Dalam penelitian ini kemampuan relawan program yang direkrut dari orang yang cukup 
berpengalaman dalam kegiatan masyarakat seperti guru, aktivis perempuan memiliki agresivitas dalam inovasi program. Selain merancang program juga terus menggali sumber daya informasi tentang lingkungan ekstern, informasi dikumpulkan, dianalisis, diproses, disimpan, diambil kembali dan disebarkan bila perlu, karena organisasi yang bekerja dalam kekosongan informasi tidak dapat membuat keputusan yang rasional. Untuk menghindari kekosongan informasi tersebut struktur interen dikoordinasikan dilatih sebagai praktik-praktik administratif manajemen yang memusatkan diri pada persoalan-persoalan intern yang dipercayai dapat melangsungkan hidupnya.

\section{Kaitan Normatif}

Secara normatif tugas kepemimpinan adalah mendorong anggota-anggota inti dan stafnya untuk mengidentifikasi kepentingankepentingannya sendiri dalam mencapai kesejahteraan organisasi tersebut. Di sini peranan kepemimpinan formal sangat diperlukan karena merekalah yang menguasai sumber daya material yang diperlukan, seperti aliran dana dan penyediaan fasilitas. Ibu ketua PPK tingkat kabupaten (istri bupati) memberi dukungan penuh terhadap program kampung KB. Karena tidak semua desa atau kelurahan menjalankan program ini dengan baik, maka Program Kampung KB di Kelurahan Karangpucung menjadi pertaruhan. Keberhasilan program ini dapat menjadi pendulum dalam memperoleh penghargaan maupun aliran dana yang datang dari propinsi. Pada tahap memperkenalkan doktrin secara prinsip tidak mengundang pertentangan yang tajam, sehingga doktrin yang disosialisikan cepat menyebar. Secara teoritis doktrin harus ada perluasan, pengungkapan, dan manipulasi yang menjadi tanggung jawab dari mereka yang membina pengembangan lembaga. Ini merupakan tahap manajemen kelembagaan dimana waktu, pemikiran dan usaha harus ditanam yang sering diabaikan. Kelalaian dalam manajemen tersebut dapat mengurangi kredibiltas, dan mungkin terbawa oportunitas ke dalam kegiatan-kegiatan yang mudah. Untuk membangun doktrin misalnya "masyarakat yang bahagia" diperlukan instrumen program (kegiatan) adaftif dengan lingkungan.

Kegiatan tersebut diantaranya lomba pidato yang mengarah ke GenRe, lomba duta Genre tingkat kabupaten. Jadi jelasnya program merupakan terjemahan doktrin ke dalam tindakan, hal ini menyangkut sekumpulan pilihan tentang bagaimana organisasi tersebut akan menerapkan sumber-sumberdaya yang telah tersedia baik material maupun jasa.

Sumber daya yang paling penting bagi organisasi adalah pengembangan staf. Pengembangan staf adalah fungsi terus-menerus dari para pembangun lembaga karena tenaga kerja dengan keterampilanketrampilan, pengetahuan, dan komitmen-komitmen yang diprogram untuk hasil kerja yang efektif. Organisasi harus bersedia mengorbankan keluaran sekarang dengan banyak program pelatihan terhadap para relawan program. Orientasi pada pengembangan struktur interen akan memperjelas misi organisasi. Struktur interen tersebut mencakup pola-pola 
wewenang formal dan informal, pembagian kerja di antara komponen-komponen, saluransaluran komunikasi diantara mereka dan metode penengahan dan pemecahan atas perselisihan. Selanjutnya akan timbul kebijakankebijakan, prioritas-prioritas, alokasi sumberdaya dan bahkan mengenai kepribadian. Beberapa pemimpin lebih tertarik dan lebih efektif dalam manajemen interen dibanding dengan membina hubungan eksteren. Kekuatan organisasi secara interen terletak pada koordinasi dan pengendalian terhadap anggota organisasi.

\section{Tersebar}

Biasanya dalam organisasi yang kompleks akan terjadi suatu proses kolektif dalam rangka program pengembangan. Gaya kepemimpinan alternatif mungkin sangat berarti mempengaruhi berkerjanya suatu organisasi baru yang berusaha membangun inovasi. Yang dimaksud dengan gaya kepemimpinan alternatif yaitu pendekatan informal dengan menggunakan bahasa lokal dan kearifan lokal. Budaya lokal seperti kesenian kentongan, lomba penyajian makana tradisonal ditampilkan dalam suasana tertentu sangat besar manfaatnya dalam meraih dukungan masyarakat.

Selanjutnya doktrin dalam kaitannya dengan kaitan tersebar menggunakan kekuatan gagasan dan lambang-lambang dalam interaksi dengan lingkungannya. Kaitan tersebar ini merupakan hubungan antara orang-orang, kelompokkelompok dan organisasi yang ikut serta dalam proses perubahan, yang dapat berpengaruh ke dalam perubahan yang positif maupun negatif. Persoalan yang dihadapi pembangunan lembaga adalah pengerahan, yaitu untuk menarik sumber-sumberdaya dapat diklasifikasi sebagai wewenang legal dan politik kepegawaian, dana-dana, peralatan, fasilitas dan informasi yang bertebaran di eksternal organisasi. Organisasi harus berjuang meraih dukungan dari kaitan yang tersebar, dengan kata lain organisasi harus punya waktu yang cukup untuk pencapaian ke sumberdayasumberdaya di masa depan. Demikian juga dengan struktur interen yang ada ternyata mampu melakukan transaksi-transaksi sosial, sehingga mekanisme kerja dapat menyesuaikan dengan perubahan lingkungan. 
Tabel

Gambaran Hasil Penelitian

\begin{tabular}{|c|c|c|c|c|c|}
\hline $\begin{array}{l}\text { Variabel } \\
\text { Kaitan }\end{array}$ & Kepemimpinan & Doktrin & Program & Sumber Daya & $\begin{array}{l}\text { Struktur } \\
\text { Internal }\end{array}$ \\
\hline $\begin{array}{l}\text { Memungkin } \\
\text { kan }\end{array}$ & $\begin{array}{l}\text { Kepemimpinan } \\
\text { formal } \\
\text { memberikan } \\
\text { akses yang lebih } \\
\text { luas, kepemimpin- } \\
\text { an tingkat opera- } \\
\text { tip mendistribusi- } \\
\text { kan informasi }\end{array}$ & $\begin{array}{l}\text { Kampung KB bukan } \\
\text { sekedar program } \\
\text { melainkan doktrin }\end{array}$ & $\begin{array}{l}\text { Membangun } \\
\text { kesejahteraan } \\
\text { bersama }\end{array}$ & $\begin{array}{l}\text { Mencari } \\
\text { sumber - } \\
\text { sumber } \\
\text { bantuan } \\
\text { material untuk } \\
\text { mendukung } \\
\text { tugas- relawan }\end{array}$ & $\begin{array}{l}\text { Relawan } \\
\text { bekerja sama } \\
\text { dan } \\
\text { memperoleh } \\
\text { insentif }\end{array}$ \\
\hline Fungsional & $\begin{array}{l}\text { Kerjasama dengan } \\
\text { kelembagan lain, } \\
\text { seperti BNN, } \\
\text { tokoh masyarakat }\end{array}$ & $\begin{array}{l}\text { Pengembangan } \\
\text { nilai-nilai efesiensi } \\
\text { dan produktif untuk } \\
\text { mendasari tindakan } \\
\text { sosial }\end{array}$ & $\begin{array}{l}\text { Tindakan2 } \\
\text { tertentu yg } \\
\text { berhubungan } \\
\text { dengan } \\
\text { pelaksanaan }\end{array}$ & $\begin{array}{l}\text { Menterjemahk } \\
\text { an masukan, } \\
\text { kritik dan } \\
\text { tantangan }\end{array}$ & $\begin{array}{l}\text { Pembagian } \\
\text { kerja } \\
\text { diinformasika } \\
\text { n secara jelas }\end{array}$ \\
\hline Normatif & $\begin{array}{l}\text { Kepemimpinan } \\
\text { formal } \\
\text { memberikan } \\
\text { arahan -arahan } \\
\text { (camat, lurah } \\
\text { PLKB), sedangkan } \\
\text { kepemimpinan } \\
\text { kader terjun } \\
\text { langsung ke } \\
\text { masyarakat }\end{array}$ & $\begin{array}{l}\text { pengembangancitra, } \\
\text { harapan, cita-cita } \\
\text { dan gaya tindakan }\end{array}$ & $\begin{array}{l}\text { alokasi energi } \\
\text { dan sumber } \\
\text { daya lainnya, } \\
\text { yang } \\
\text { berhubungan } \\
\text { dengan } \\
\text { lingkungan } \\
\text { internal dan } \\
\text { eksternal }\end{array}$ & $\begin{array}{l}\text { Sumberdaya } \\
\text { kekuasaan } \\
\text { harus } \\
\text { bersinergi } \\
\text { dengan sumber } \\
\text { daya relawan }\end{array}$ & $\begin{array}{l}\text { pola } \\
\text { wewenang, } \\
\text { sistem } \\
\text { komunikasi, } \\
\text { komitmen } \\
\text { terhadap } \\
\text { program } \\
\text { Terjalin } \\
\text { dengan } \\
\text { lancar }\end{array}$ \\
\hline Tersebar & $\begin{array}{l}\text { Menggunakan } \\
\text { tokoh-tokoh } \\
\text { karismatik untuk } \\
\text { membangun } \\
\text { partisipasi }\end{array}$ & $\begin{array}{l}\text { Hasil proyeksi atas } \\
\text { kondisi internal dan } \\
\text { eksternal }\end{array}$ & $\begin{array}{l}\text { Efisiensi } \\
\text { pengeluaran } \\
\text { rumah tangga } \\
\text { dan } \\
\text { kesejahteraan } \\
\text { dipersatukan }\end{array}$ & $\begin{array}{l}\text { Melakukan } \\
\text { pendekatan } \\
\text { dengan } \\
\text { perseorangan } \\
\text { dan kelompok } \\
\text { yang tidak } \\
\text { terorganisasi }\end{array}$ & $\begin{array}{l}\text { Struktur } \\
\text { internal } \\
\text { menginisiasi } \\
\text { secara aktif } \\
\text { dengan } \\
\text { sumber - } \\
\text { sumber } \\
\text { eksternal }\end{array}$ \\
\hline
\end{tabular}

\section{Kesimpulan}

Kaitan yang memungkinkan (enabling) telah menyediakan wewenang untuk bekerja dan mencapai sumber-sumber daya yang esensial. Fokus perhatian kepemimpinan formal dan informal menyatu dalam koordinasi yang baik, sementara doktrin belum dapat dicapai secara maksimal.

Kaitan-kaitan fungsional telah menyediakan masukan-masukan yang diperlukan ke dalam program, sedangkan doktrin dan program masih terus-menerus dilakukan secara inovatif sehingga keluarannya belum spesifik. 
Kaitan-kaitan normatif adalah hubungan-hubungan dengan organisasi-organisasi lainnya menghasilkan metode-metode yang fisibel. Kepemimpinan, doktrin, program, sumberdaya dan struktur interen telah terjadi kolaborasi yang sistematis.

Kaitan-kaitan yang tersebar telah terikat dengan komitmenkomitmen awal program tetapi masih diperlukan tindakan yang nyata dan keberlangsungan untuk pelembagaan program. Pengaruh kepemimpinan informal masih tinggi tetapi kohesivitas sosial belum terjadi, sehingga doktrin harus diperbaruhi program harus inovatif dan sumber daya ditingkatkan.

\section{Referensi}

Anantanyu, Sapja. 2011. Kelembagaan Petani: Peran dan Strategi Pengembangan Kapasitasnya. SEPA, Vol. 7(2): 102-109.

Daymon, Christine, dan Immy Holloway. 2008. Metode-metode Riset Kualitatif dalam Public Relations dan marketing Communications. Bentang Pustaka: Yogyakarta.

Hanafie, Rita. 2010. Pengantar Ekonomi Pertanian. CV. Andi Offset: Yogyakarta.

Nugroho, Bramasto. 2010.

Pembangunan Kelembagaan

Pinjaman Dana Bergulir Hutan

Rakyat. JMHT, Vol. 16(3): 118125

Ansell, Chris; Alison Gash. 2007. Collaborative Governnance in Theory and Practice. Journal of Public Administration Research and Theory.Advance Acces Published

Dewi, In, Achmad; Priyo, Kusumedi. 2012. Kajian Keterlibatan Multipihak dalam

Pelaksanaan Peraturan

Perundang-undangan mengenai Hutan Lindung di Kabupaten Pangkep. Balai Penelitian Kehutanan Makasar

Dwiyanto, Agus, 2005. Memujudkan Good Governance melalui Pelayanan Publik. Yogyakarta Gajah Mada University Press.

Miles dan Heberman Terjemahan Sutopo Herebetus. 2003. Pengantar Metode Kualitatif dan Dasar-dasar Teoritis. Surakarta. Pusat Penelitian UNS

Moleong, Lexy J. 2015. Metode Penelitian Kualitatif. Bandung Remadja Karya

Sedarmayanti. 2003. Good Governnance (Kepemerinatahan yang Baik) dalam Rangka Otonomi Daerah Bandung. Mandar Maju

Sukarso, dkk, 2016. Model Keterlibatan Pihak Ketiga dalam Proses Kebijakan Pemberdayaan Masyarakat di Tingkat Kabupaten. Proseding Seminar Nasional tentang Pengembangan Sumber Daya Manusia dan Kearifan Lokal Berkelanjutan. Unsoed Purwokerto 